\title{
A CASE OF WATERING EYE DUE TO PTERYGIUM*
}

BY

\author{
F. J. DAMATO \\ Malta
}

Patients suffering from pterygium do not usually complain of anything. Advice is generally sought because the patient is told by his friends that something, a piece of skin, is growing on the eye. In Malta, pterygium is popularly known as "karnita ", octopus. The patient is very upset by the information that this marine inhabitant is gnawing at the eye, and soon asks for treatment. The particular interest attaching to this case was that epiphora was the chief accompanying sign of pterygium.

Fuchs (1917) gives a masterly and detailed description of pterygium. No mention is made of lacrimation. Duke-Elder (1938), De Schweinitz (1913), and Gifford (1938), say nothing about pterygium as one of the causes of watering eyes.

\section{Case Report}

G. C., 44 years old, a dockyard fitter, came to consult me on July 26, 1949. He said that his eyes were watering as they once used to do when he was suffering from pterygium. He had been operated upon for pterygium in the right eye in 1941 and in the left eye in 1943.

On examination, pterygia were found on the nasal side in each eye. That in the right eye was large and fleshy, and extended to within $3 \mathrm{~mm}$. of the corneal centre. Closer observation revealed that the upper lid margin, medial to the upper lacrimal punctum, was attached to the pterygium and that the punctum was displaced inwards.

Vision R.E. $c-1.5$ ax., $90=6 / 5$.

Vision L.E. unaided, 6/

No evidence of trachomatous changes.

I performed a McReynold's transplantation on the right eye and severed the connection between the lid margin and the pterygium. The conjunctival wound healed well and the patient was completely relieved of the lacrimation. The pterygium in the left eye was transplanted a week later.

Three months later the right eye had started to water again. Examination of the eye revealed a jelly-like mass, flanked by granular tissue, covering the site of the old pterygium. The inner angle of the lid margin was once more adherent to it. This time, I covered the bare area left over after excision of the pterygium, by bringing from above and below two-tongue-shaped strips of conjunctiva which I sutured together in the horizontal meridian. The wound healed well and when seen five months after the last operation the pterygium had not recurred, and the eye had stopped watering. The upper lid margin had remained completely free.

One might think that the epiphora was due to the existence of the fleshy pterygium, adherent to the upper lid margin, with deviation of the upper lacrimal punctum, or perhaps to the fact that the presence of a fairly large mass in the lacus lacrimalis hindered the normal flow of tears to the lacrimal punctum. I have made a point of asking all patients suffering from pterygium about watering eyes. Four of them have answered that it was a watering eye that made them aware that there was something wrong.

\footnotetext{
* Received for publication May 5, 1950.
} 
Some observations on the aetiology and surgery of pterygium will not be out of place. Climatic conditions are important factors. Continuous and violent gusts of wind with their usual accompaniment of hard, stony dust are a frequent occurrence in this island. Pterygium is rather common here, and my impression is that it is usually found in people who spend a good part of the day in the open air. However, I have seen it in quite a number of housewives who are most of the time indoors.

All the cases I have seen were on the nasal side, except one. In this particular case, there was a pterygium on the nasal side in the left eye, and in the right eye, a pterygium on the nasal side reached to within : $\mathrm{mm}$. of the corneal centre, and another one on the temporal side also extended to about $2 \mathrm{~mm}$. from the centre. A narrow pupillary area remained free. Vision in this eye was reduced to $6 / 18$. The patient, an old man aged 70 years, has been suffering from pterygia in both eyes for 15 years.

I have found McReynold's transplantation a satisfactory operation. In a consecutive series of over fifty cases, two pterygia recurred. I have been using Herbert's keratome $3.5 \mathrm{~mm}$. wide, which is easier to handle than either a Graefe knife or a scalpel. to dissect the apex and body of the pterygium from the corneal surface. It is necessary to remove the episcleral tissue of the bare area which remains after transplantation of the pterygium, and to cover it by pulling the adjacent conjunctiva on to it by one or two stitches.

Nobody in Malta would ever dream of consulting an ophthalmic optician to have his eyes tested for glasses. Everybody goes to the eye doctor. A great many people, however, still ask for the services of old women who, for ages, have been reputed to be able to remove pterygia by means of a shell, which is popularly thought to be extracted from the head of the octopus, but is really the operculum of Trochus Rugosus, a salt water snail found in the Grand Harbour. The ophthalmic surgeon is only consulted when, in spite of the magician's efforts, the "octopus" is seen to be still clinging to the eye.

\section{REFERENCES}

DUKE-Eldek, W. S. (1938). "Text-book of Ophthalmology", Vol. II, p. 2,000. Kimpton, London.

FUchs, H. E. (1917). "Text-book of Ophthalmology", 5th ed., p. 213. Lippincott, Philadelphia and London.

GIFFORD, S. R. (1938). "Text-book of Ophthalmology", p. 167. Saunders, Philadelphia and London.

DE Schweinitz, G. E. (1913). "Diseases of the Eye", 7th ed., p. 204. Saunders, Philadelphia and London. 